\title{
BIOLOGICAL VEGETATION MANAGEMENT: AN ALTERNATIVE TO CHEMICAL PESTICIDES
}

\section{By Jack Eric Vandenbroucke ${ }^{1}$, Catherine Gaucher ${ }^{2}$, and Norbert Major ${ }^{3}$}

\begin{abstract}
We present data collected at 3 and 6 years on a rightsof-way project with Myco-Tech ${ }^{\mathrm{TM}}$ paste. This paste is based on a naturally occurring fungus (Chondrostereum purpureum (Pers. ex Fr.) Pouzar) in temperate climates that initiates wood decay. The project was done in Ste-Agathe, Québec, Canada, in 1998. After 6 years in the treated area, sprouting was sparse (density $=22,500$ stems/ha $[9,000$ stems/ac]), and mean height was approximately $2.6 \mathrm{~m}(8.6 \mathrm{ft})$. In the control area, sprouting was uniform (density $>132,500$ stems/ha [53,000 stems/ac]) and mean height was approximately $6 \mathrm{~m}$ (20 ft). According to Hydro-Québec's clearance standard at that site, the control area should have been cut last year. In the treated area, clearing is not needed for at least 3 to 4 years.
\end{abstract}

Key Words. Biological vegetation management; Chondrostereum purpureum; competitive deciduous species; contour maps; herbicide, Integrated Vegetation Management; mechanical cutting; Myco-Tech ${ }^{\mathrm{TM}}$; pesticide; resprouting; rights-of-way; stump treatment.

In light of the 2003 blackout in the United States and Canada, vegetation management has been an important topic for arborists and rights-of-way (ROW) managers (USDOE and MNRC 2004). It has unveiled a large concern in the public in terms of power grid reliability and the capacity of managers to secure service. Having to deal with a large array of regulation, public pressure for environmental protection, budget concerns, and increasing demand, managers are faced with the difficult task of making the best choices, although the right tools are not always available to them. This situation is not specific to power grid ROWs but exists also in gas, roadside, or railroad ROWs.

Reliability of the service is the utmost objective for ROW managers. Minimizing outage and time to repair can be accomplished only if vegetation management is under control at all times. However, tools such as mechanical cutting, chemical pesticides, and risk management do not always meet new standards, which are often imposed by social pressure. Reduction in chemical pesticide/herbicide use and a trend toward eliminating herbicides near populated areas leads to increasing buffer zones in number and size (Owens 1999; EPRI 2003).

To address the above-mentioned problems, several projects were launched in the early 1990s to find an alternative to chemical pesticide use (Jobidon 1991). The use of Chondrostereum purpureum (Pers. ex Fr.) Pouzar as a bioherbicide against unwanted vegetation has been considered in Europe (Scheepens and Hoogerbrugge 1989; De Jong et al. 1990) and in Canada (Wall 1990, 1994; Wall et al. 1992). Extensive study to develop a safe and effective biological vegetation management tool has been conducted in Québec, Canada, since 1992 (Gosselin 1998; Goulet 1998). That research led to a product (Myco-Tech TM product) that received its registration number in April 2002 for inhibition of regrowth on cut stumps of deciduous tree species in rights-of-way and conifer release management situations (PMRA 2002). EPA registration is under final revision and was expected to conclude by mid-2005.

Chondrostereum purpureum is a lignicolous, naturally occurring basidiomycete fungus commonly found in temperate deciduous forests. It does not cause diseases in coniferous tree species (Etheridge and Morin 1963), but it is a pathogen of various deciduous trees and a primary colonizer of freshly wounded tissues (i.e., pruning, wind damage, frost cracks) and cut hardwood stumps and logs (Etheridge and Morin 1963; Rayner 1978, 1979). Colonization occurs via airborne basidiospores (Kemp and Burden 1986). In stumps, it is not combative and is easily replaced, often after 6 to 12 months, by a wide range of other fungi (Rayner 1978, 1979; Gosselin 1996). Target species include most of the woody broadleaf species such as Betula papyrifera Marsh. (paper birch), Betula alleghaniensis Britt. (yellow birch), Acer saccharum Marsh. (sugar maple), A. spicatum Lam. (mountain maple), A. rubrum L. (red maple), Prunus pensylvanica L.f. (pin cherry), Populus tremuloides Michx. (quaking aspen), Salix spp. (willow), Alnus rugosa Spreng. var. americana (Regel) Fern. (speckled alder), Corylus cornuta Marsh. (hazelnut), Quercus rubra L. (red oak), and Fagus grandifolia J. F. Ehrh. (American beech).

Myco-Tech gel is a formulated product containing viable mycelium but not spores of C. purpureum. The Québec Strain HQ1 was identified with a DNA analysis (Gosselin et al. 1996) and has been patented (CA2451038 and PCT pending). Myco-Tech gel is applied as a thin layer over the surface area of freshly cut stumps of deciduous species within 30 min of cutting. Following application of MycoTech, extensive spread of hyphae takes place throughout the xylem and inhibits resprouting and regrowth (PMRA 2002). It causes brown staining and wood decay. Depending on species, wood devitalization may take from a few 
months up to 3 years. Sprouts that are not dead remain chlorotic and show signs of necrosis.

Toxicology and eco-toxicology studies have been conducted by independent laboratories in Canada and the United States for almost 10 years as part of the registration process (PMRA 2002). For the environment, the conclusion states that there is no effect on nontarget species, no effect on conifers, and no hazard to wildlife. Myco-Tech will not increase the natural occurrence of $C$. purpureum because of the use of mycelium instead of spores (Goulet 1998; Gosselin et al. 1999). Health studies also clearly demonstrate that it is not harmful to human health and is not irritating to skin and eyes. Furthermore, the fungus does not develop at a temperature higher than $37^{\circ} \mathrm{C}\left(98.6^{\circ} \mathrm{F}\right.$, body temperature).

This paper presents data from a ROW project (HydroQuébec) to evaluate the use of the biological treatment Myco-Tech for ROW vegetation management of deciduous trees. We propose a new way to visualize raw data of surveys using contour maps and 3D surfaces, allowing rapid evaluation of the efficiency of a biological control.

\section{MATERIALS AND METHODS Study Area}

In 1998, Gosselin (1998) established two adjacent study areas in a randomized complete block design, B1 and B2 for Canadian registration purposes, north of Montréal near SteAgathe-des-Monts $\left(46^{\circ} 03^{\prime} \mathrm{N}, 74^{\circ} 17^{\prime} \mathrm{W}\right)$. The experimental installation was established in Hydro-Québec span \#430 of the power line \#7044-7047 (735 kV), at the south end of an area chemically treated in 1997.

\section{Experimental Installation}

Each randomized complete block (B1 and B2) of approximately $0.5 \mathrm{ha}(1.1 \mathrm{ac})$ included four replications of two treatments (control: mechanical cutting with brush saw only; treated: mechanical cutting with brush saw + MycoTech application) for a total of eight plots per block. In each plot, we installed 10 subplots (radius $=1.13 \mathrm{~m}[3.7 \mathrm{ft}]$ ) on a transect, for a total of 80 subplots per block.

\section{Topology, Soil, and Vegetation Composition}

Elevation in the study area ranged from an estimated 425 to $455 \mathrm{~m}$ (1,390 to 1,490 ft). Block B1 faced north, while block B2 faced south. All slopes were less than 10\% toward a beaver marsh and a brook. Soil formation was rich and mainly contained a thick humus cover. Block B1 was welldrained, while block B2 was a bit rocky, the soil less rich with hilltop structure. The area is situated in a mixed forest (Canadian Ecozone 4, Canadian Plant Hardiness Zone, Agriculture and Agri-Food Canada). The power line has been maintained through clearing every 4 to 5 years for at least the past 20 years. The last clearing was in 1993.

\section{Initial Survey}

The following deciduous species were found in the study area: Betula alleghaniensis (yellow birch) (2\%), Prunus pensylvanica (pin cherry) (8\%), Acer rubrum (red maple) (22\%), A. saccharum (sugar maple) (18\%), A. spicatum (mountain maple) (4\%), Populus tremuloides (quaking aspen) (14\%), and Salix spp. (willow) (21\%). Initial densities of the control areas were 24,000 stems/ha $(9,700$ stems/ac) in B1 and 53,000 stems/ha (21,500 stems/ac) in $\mathrm{B} 2$, while initial densities in the treated areas were 45,000 stems/ha (18,200 stems/ac) in B1 and 52,000 stems/ha (21,000 stems/ac) in B2.

\section{Treatments}

Treatments were performed between 17 and 31 August 1998. Myco-Tech paste formulation (Chondrostereum purpureum strain $\mathrm{HQ1}$ ) at a concentration of 1.0 to $2.8 \times$ $10^{6} \mathrm{CFU} / \mathrm{g}$ was applied. Application of 0.5 to $1 \mathrm{~mL}$ per stump was done within 5 min of the cut.

\section{Surveys}

Surveys were done in July 1999, in the last week of June and the first week of July 2000, and in the last week of July 2001 by three independent firms. In each subplot, every stump was surveyed and categorized as dead or living. For each living stump, species, status (dead or alive), height, and diameter (at $15 \mathrm{~cm}$ [6 in.] from the ground) of each sprout were surveyed.

\section{Data Treatment}

We developed an approach to visualize the effectiveness of the treatment on a contour map representation using the height of the sprouts. Because survey plots are designed to be representative of the entire experimental area, height of sprouts are positioned on grid coordinates. We made a grid matrix $26 \times 27$ (696 stems and 6 blanks) for the treated area and a $18 \times 19$ matrix (342 stems and no blanks) for the control area. Each matrix coordinate represented the measured height of each sprout (blanks are ignored by the software, so they do not interfere in the contour lines calculation). We used the topographic software Surfer version 8.0 (Golden Software, CO) to first compute the grid file and then draw contour maps and their 3D representations, which can be interpreted as ligneous vegetation cover representation.

\section{Statistical Analysis}

Effect of the Myco-Tech treatment on the mean height of highest sprouts was tested by a one-way ANOVA. All P values $<0.05$ were considered significant. Statistical analysis was performed with JMP version 5.1. software (SAS Institute, Cary, NC). Confidence intervals were evaluated using $\alpha=0.05$. 


\section{RESULTS AND DISCUSSION Development of Competing Deciduous Species} Table 1 shows data 3 years after treatment. The mortality rate of the stumps in the treated area was different after 3 years $(65 \%)$. Mean height was significantly lower in treated areas (with an average of $56 \mathrm{~cm} \mathrm{[22} \mathrm{in.])} \mathrm{than} \mathrm{in} \mathrm{control}$ areas (average of $175 \mathrm{~cm}$ [69 in.]) $(P<0.0001)$. Maximum height of few sprouts (less than 10 out of 696) was similar in treated and control areas. Based on the $P$ value and confidence interval, we suspect that some stumps were missed when the treatment was applied in the treated area.

Density was evaluated at a height of $1.3 \mathrm{~m}(4.3 \mathrm{ft})$ and was probably the most significant factor, with 22,500 stems/ha $(9,000$ stems/ac) in the treated area compared to 132,500 stems/ha $(53,000$ stems/ac) in the control area (Table 1). The height distribution showed major differences in the treated area compared to the control area. After 3

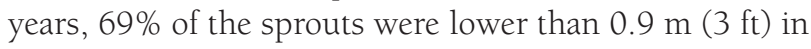
the treated area compared to $87 \%$ of the sprouts between

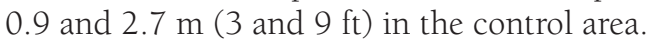

We plotted the curves of sprout growth over a 3-year period in the treated and control areas in each block design (Figure 1). Although topology and soil composition were different among blocks, we saw a similar response in both treated and control growth curves, indicating that the effect of the treatment was larger than the potential effect due to the soil conditions. In the treated site, growth curve B2 showed a decrease on mean height of sprouts. We actually saw an increase in mortality rate in the third year, indicating that the treatment has a long-term effect in controlling the growth of the sprouts, although the effect was due to organisms other than the initial Myco-Tech treatment (Rayner 1978, 1979).

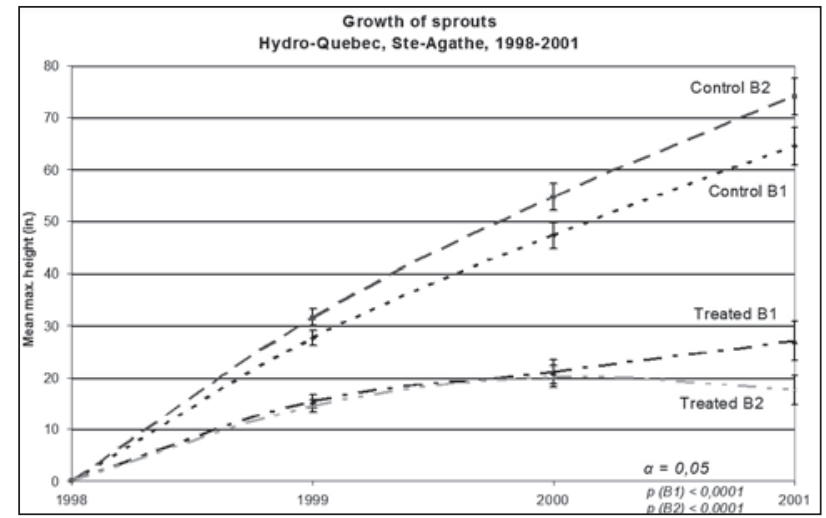

Figure 1. Growth of sprouts for blocks B1 and B2 over 3 years in treated and control areas.

\section{Contour Maps Representation}

The contour map and the 3D surface representation 3 years after treatment are presented in Figure 2. Each $\mathrm{X}-\mathrm{Y}$ grid coordinate represented a sprout, and the $Z$ value indicated the height of the sprouts in inches.

Traditionally, contour maps are used to represent topographic data. In forestry, the same approach can be used if, instead of geographic elevation, heights of trees are positioned on a grid coordinates. This is called a geographic information system (GIS), in which tree information is collected via satellites. In our approach, we applied GIS principles to a smaller application, silviculture, where sprout elevation and position were physically measured and plotted on a grid. From that grid, lines with same elevation were computed and plotted, giving contour lines (also called contour maps). On a contour map, the closer together the lines are, the steeper the slope, indicating that heights of sprouts varied greatly over a short distance (from one adjacent coordinate to the other). This was observed in contour map of the treated area (Figure 2B). On the other hand, spread-out contour lines indicated a gentler slope between adjacent coordinates or sprout height, meaning a more uniform height distribution of sprouts. This was observed in control area (Figure 2A).

In order to evaluate the vegetation cover and the treatment efficiency, a color scale was used (shown in black and white in Figure 2) to quickly visualize the height of the vegetation. In ROW management, peak distribution on the contour map is an evaluation of the resprouting density, which can represent a potential danger for power lines. Color scale gave the height in inches of those peaks. The contour map of the treated area (Figure 2B) showed a large fraction of the surface with a height of 0 , meaning that all sprouts were dead, establishing a high level of efficacy of the treatment 


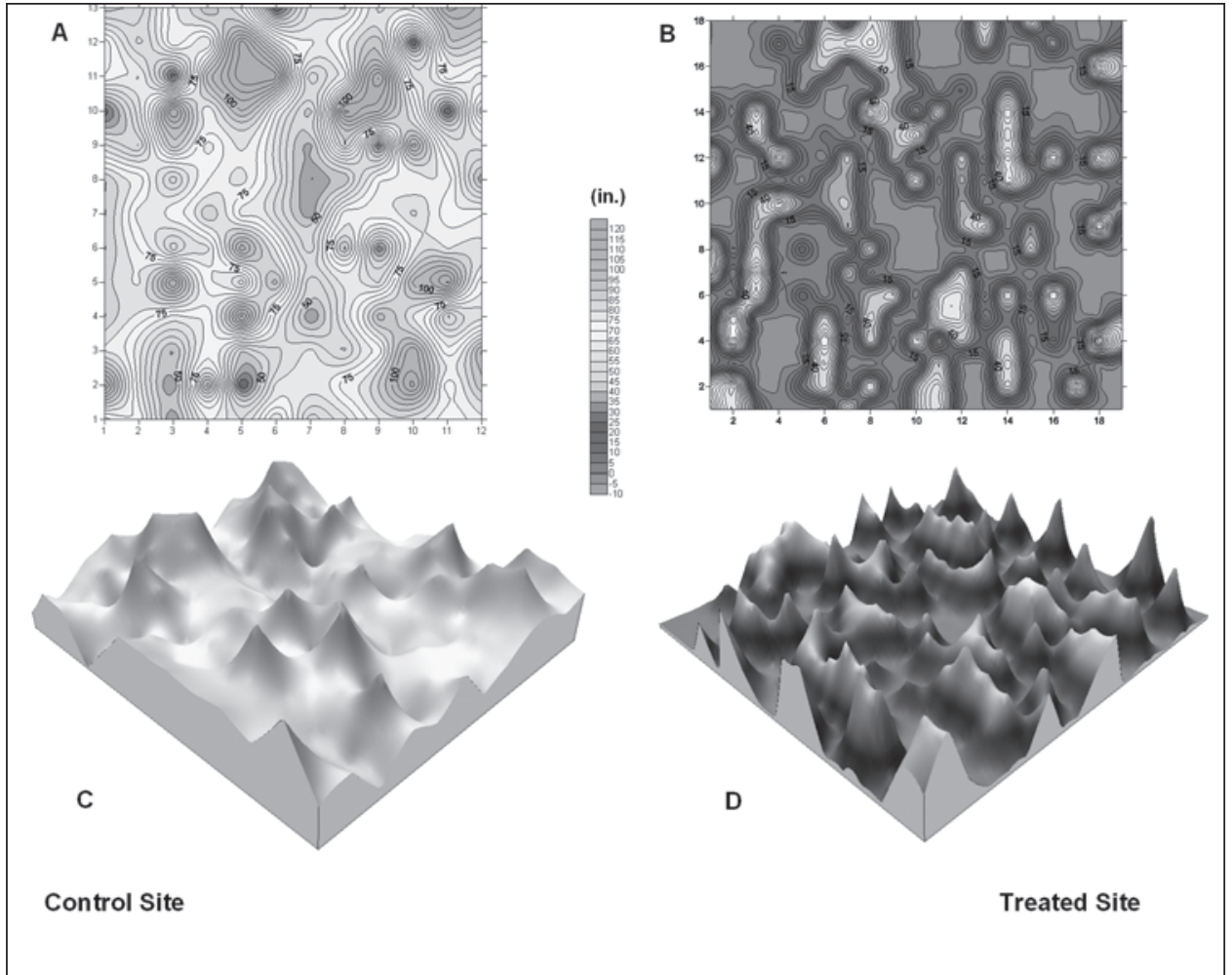

Figure $2 *$. Contour map $(A, B)$ and $3 D$ surface representation $(C, D)$ in control and treated areas, respectively, for blocks B1 and B2. Height of the sprouts is given in inches.

(65\%, Table 1). On the contrary, the contour map of the control area (Figure 2A) showed that almost all the surface was higher than $1.78 \mathrm{~m}(5.9 \mathrm{ft})$, thus showing high density of the return pattern of ligneous sprouts. This approach can then be used to evaluate the return cycle needed for a site. If GPS coordinates were associated with raw data, a maintenance crew can be sent to appropriate areas in a ROW.

As in the GIS technique, another advantage of the visual technique presented here is that we can compute a 3D surface representation of the contour map (Figures 2C and 2D). Surfaces have been computed based on three Simpson's rule numerical calculations (extended, trapezoidal, and 3/8). This 3D representation gave a better view of the spatial distribution and the sparseness and the height of the resprouting obtained after the use of Myco-Tech, thus helping arborists in making a "virtual walk" within the area (one option of the software allows this kind of animation). This visual technique is an efficient tool to clearly and rapidly explain and interpret great amounts of raw and statistical data (skewness and kurtosis) about the effectiveness of a treatment. Moreover, evolution of the heights of resprouting can be visualized over a period of years using an overlaid contour map comparison on the same area.

*Full-color versions of the figures in this article are available at www.isa-arbor.com/publications/vandenbroucke.aspx.

\section{CONCLUSION}

However, for 3D surface representation, volume calculation cannot be used directly to evaluate biomass decrease as a measure of treatment effectiveness, because it does not calculate stem volume but rather evaluates a conical surface from the top of a stem to the adjacent one. Another method is used to evaluate total volumetric biomass reduction following a biological treatment (Vandenbroucke et al. 2005).

\section{Ste-Agathe: 6 Years Later}

In Ste-Agathe, thorough surveys were stopped in 2001. Nonetheless, each following year, we returned to the site to look at the condition of the area. In August 2004, we took pictures of control and treated areas. In the treated area (Figure 3) heights of sprouts were approximately $2.6 \mathrm{~m}$ (8.6 ft), and few seedlings (natural regeneration) were seen. Sprouts were still very sparse on the treated area, and density was still around 22,500 stems/ha (9,000 stems/ac). As seen in Figure 4 , groundcover consisted mainly of different species of herbaceous plants, raspberries, and low groundcover (i.e., moss, Ledum greenlandicum). In the control area (Figure 4), mean height was between 5.5 and $6 \mathrm{~m}$ (18 and $20 \mathrm{ft}$ ), and density was over 132,500 stems/ha (53,000 stems/ac). The coverage of the area was homogeneous in height and density. The control area should have been cut last year according to Hydro-Québec's clearance standard at that area. In the treated area, in view of the low density (sparseness of sprouting) and low average height, clearing was not required for at least 3 to 4 years. Thorough surveys are planned for the future, in years 8 and 10 .

Myco-Tech treatment has proven to be a long-lasting, viable, and efficient alternative to increase the effectiveness of mechanical cutting in rights-of-way. This technology demonstrates direct and indirect advantages: It maintains a low-level vegetation pattern, thus promoting biodiversity and a stable temperature on the ground. It helps keep humidity near the ground and provides a more uniform shelter for wildlife.

This treatment can be used in Integrated Vegetation Management (IVM) planning to control a broad spectrum of 


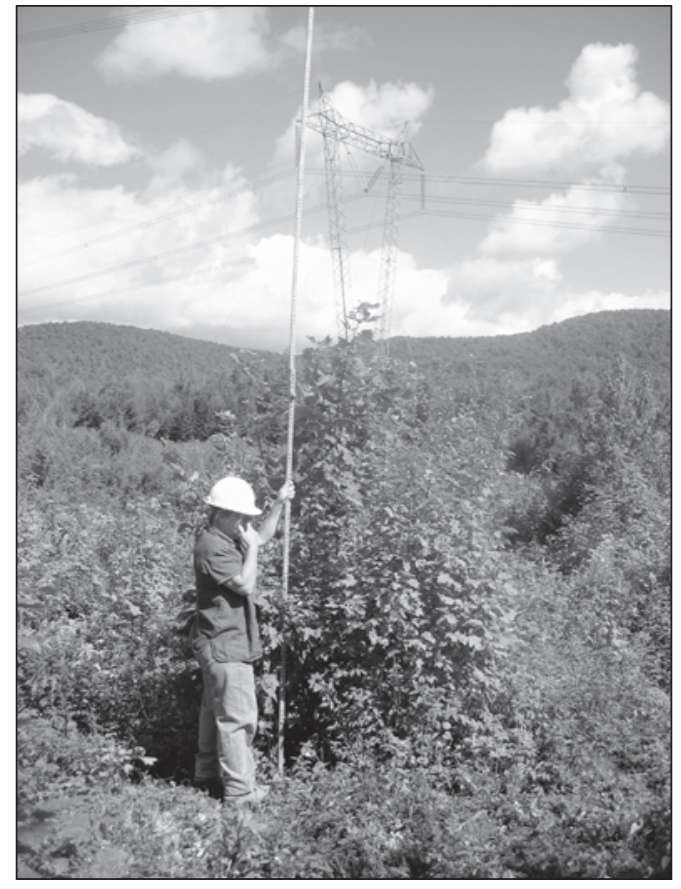

Figure 3. Treated area behind technician 6 years after treatment, August 2004. Mean height: $2.6 \mathrm{~m}(8.6 \mathrm{ft}$.)

woody, broadleaf species. By reducing the need to clear every 4 to 5 years, the manager can make better decisions on resource allocation, thereby decreasing the need for risk management. This translates into a return cycle on ROWs of up to 8 to 10 years in most cases. If a return is required, it would be on a small portion of the area (typically less than 20\%). The lower density gives a better access to employees and contractors. Outage risk is significantly decreased because repair duration is lowered as a result of easier and faster access. This product might also be used as a cornerstone for an environmental image strategy for ROW management. Myco-Tech would be a suitable solution in many sensitive or protected areas and buffer zones.

\section{LITERATURE CITED}

De Jong, M.D., P.C. Scheepens, and J.C. Zadoks. 1990. Risk analysis for biological control: A Dutch case study in biocontrol of Prunus serotina by the fungus Chondrostereum purpureum. Plant Dis. 74: 189-194.

Etheridge, D.E., and L.A. Morin. 1963. Colonization by decay fungi of living stems of balsam fir following artificial injury. Can. J. Bot. 41:1532-1534.

Electric Power Research Institute (EPRI). 2003. Destinations 2003: ROW Environmental Issues in Siting, Development and Management. EPRI, Palo Alto, CA. 10 pp.

Gosselin, L. 1996. Maitrise biologique de la reproduction vegetative chez des feuillus, dispersion et variabilité génétique de l'agent microbien impliqueé, Chondro-

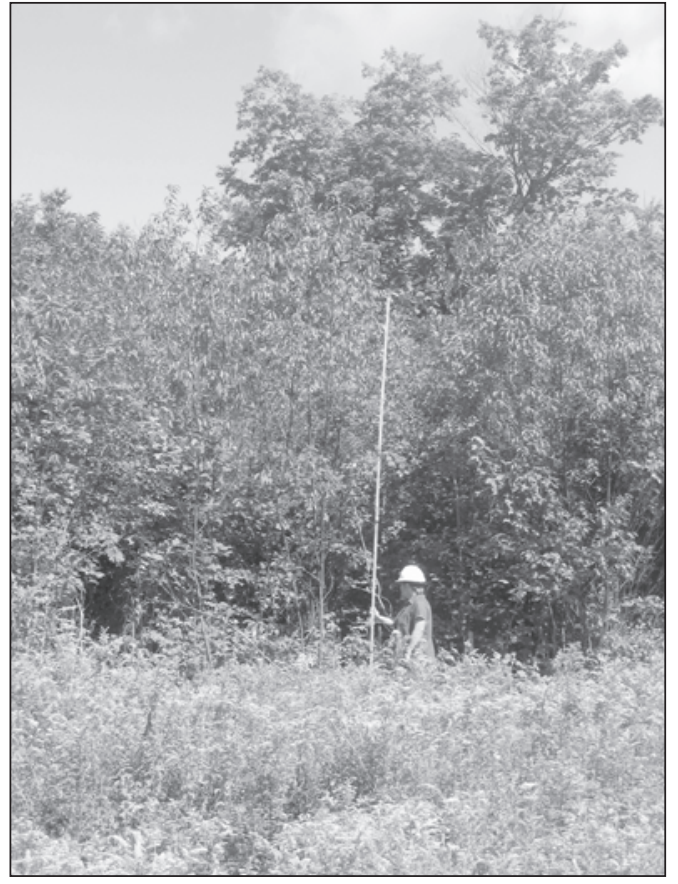

Figure 4. Control area behind technician 6 years after treatment, August 2004. Mean height: $6 \mathrm{~m}$ (20 ft).

stereum purpureum. Ph.D. dissertation. Laval University, Québec. 133 pp.

_ 1998. Experimental Installation, Ste-Agathe-desMonts Project. Internal report.

Gosselin, L., R. Jobidon, and L. Bernier. 1996. Assessment of genetic variation within Chondrostereum purpureum from Québec by random amplified polymorphic DNA analysis. Mycol. Res. 100:151-158.

_ 1999. Biological control of stump sprouting of broadleaf species in ROW with Chondrostereum purpureum: Incidence of the disease in non-target hosts. Biol. Cont. 16:60-67.

Goulet, A. 1998. Epidemiology of the fungus Chondrostereum purpureum, a biological control agent of the asexual reproduction of deciduous tree species in forest environment. Master's thesis. Laval University, Québec. 92 pp.

Jobidon, R. 1991. Some future directions for biologically based vegetation control in forestry research. For. Chron. 67:514-519.

Kemp, M.S., and R.S. Burden. 1986. Phytoalexins and stress metabolites in the sapwood of trees. Phytochemistry 25:1261-1269.

Owens, K.1999. The right way to vegetation management: A review of selected pest management policies and programs on rights-of-way. Beyond Pesticides: Pesticides and You 19:9-17. 
Pest Management Regulatory Agency, Health Canada (PMRA). 2002. Proposed Regulatory Decision Document PRDD2002-01. www.pmra-arla.gc.ca/english/pdf/prdd/ prdd2002-01-e.pdf (accessed 8/1/05).

Rayner, A.D.M. 1978. Interactions between fungi colonising hardwood stumps and their possible role in determining patterns of colonisation and succession. Ann. Appl. Biol. 89:131-134.

- 1979. Internal spread of fungi colonising hardwood stumps. New Phytol. 82:505-517.

Scheepens, P.C., and A. Hoogerbrugge. 1989. Control of Prunus serotina in forests with the endemic fungus Chondrostereum purpureum, pp. 545-551. In Delfosse, E.S. (Ed.). Proceedings, 8th International Symposium on Biological Control of Weeds, 6-11 March 1988, Rome, Italy.

United States Department of Energy and Ministry of Natural Resources of Canada (USDOE \& MNRC). 2004. Final Report on the August 14, 2003, Blackout in the United States and Canada. U.S.-Canada Power System Outage Task Force, Causes and Recommendation. 238 pp.

Vandenbroucke, J.E., C. Gaucher, and N. Major. 2005. Biological control of deciduous vegetation with Chondrostereum purpureum. North. J. Applied For. (paper submitted).

Wall, R.E. 1990. The fungus Chondrostereum purpureum as a silvicide to control stump sprouting in hardwoods. North. J. Appl. For. 7:17-19.

- 1994. Biological control of red alder using stem treatments with the fungus Chondrostereum purpureum. Can. J. For. 24:1527-1530.

Wall, R.E., R. Prasad, and S.F. Shamoun. 1992. The development and potential role of mycoherbicides for forestry. For. Chron. 68:736-741.

Acknowledgments. We wish to extend our most sincere thanks to Arboréa, Groupement forestier des Hautes-Laurentides, and Horizons Multi-Ressources for field assistance during the project.

$1^{*}$ Director of Engineering

Myco-Forestis Corp.

1219, rue Jean Vincent

Carignan, Québec, J3L 3P9, Canada

jackeric@videotron.ca

${ }^{2}$ Director of Laboratories

Myco-Forestis Corp.

4892, rue Fulton

Montréal, Québec, H3W 1V3, Canada

${ }^{3}$ Chief Executive Officer

Myco-Forestis Corp.

801 , route 344

L'Assomption, Québec, J5W 4M9, Canada

*Corresponding author.
Résumé. Cet article présente des données colligées sur trois et six ans d'un projet sur une emprise où le produit Myco-Tech ${ }^{\mathrm{TM}}$ a été utilisé. Ce produit est basé sur un champignon (Chondrostereum purpureum (Pers. ex FR) Pouzar) retrouvé naturellement en climat tempéré et qui initie un processus de carie du bois. Le projet a été réalisé à Sainte-Agathe (Québec) au Canada en 1998. Après six ans au sein de l'unité traitée, la formation de rejets était faible (densité de 9000 tiges/acre) et la hauteur moyenne était approximativement de 2,6 m. Au sein de l'unité témoin, les rejets étaient uniformément répartis (53000 tiges/acre) et la hauteur moyenne était approximativement de $6 \mathrm{~m}$. En fonction de la norme de dégagement dictée par Hydro-Québec pour ce site, l'unité témoin aurait dû être coupée l'année précédente. Au sein de l'unité traitée, aucun dégagement n'est requis avant trois ou quatre ans.

Zusammenfassung. Wir stellen hier Daten aus einem 3- und 6jährigen Projekt im Bereich einer Überlandleitung unter Verwendung von Myco-Tech ${ }^{\text {TM}}$ Paste. Diese Paste basiert auf einem natürlich vorkommendem Pilz (Chondrostereum purpureum (Pers. ex Fr) Pouzar) in gemäßigtem Klimaten, der Holzverfall anzeigt. Das Projekt wurde 1998 in St Agathe, Quebec, CAN, durchgeführt. Nach 6 Jahren war das Sprießen in der behandelten Fläche dünn (9000 Pfl./acre) und die durchschnittliche Höhe lag bei 2,6 m. In der Kontrollfläche war das Keimen einheitlich (53.000 Pfl./acre) und die durchschnittliche Höhe betrug 6 m. In Bezug auf den Hydro-Quebec-Durchforstungsstandard an diesem Standort sollte die Kontrollfläche letztes Jahr geschnitten werden. In der behandelten Fläche ist ein Schnitt für die nächsten 3-4 Jahre nicht nötig.

Resumen. Se presentan los datos colectados en 3 y 6 años de un proyecto de derecho de vía con pasta Myco-Tech ${ }^{\mathrm{TM}}$. Esta pasta está basada en un hongo que ocurre naturalmente (Chondrostereum purpureum (Pers. ex Fr) Pouzar) en clima templado que inicia el decaimiento de la madera. El proyecto fue hecho en Ste-Agathe, Quebec, Canadá en 1998. Después de 6 años en el área tratada, el rebrote fue esparcido (densidad $=9,000$ tallos/acre) y la altura media fue aproximadamente $2.6 \mathrm{~m}$ (102 pulg.). En el área de control el rebrote fue uniforme (densidad $>53,000$ tallos/acre) y la altura media fue aproximadamente 6 m (236 pulg.). De acuerdo al estándar de aclareo Hydro-Quebec en ese sitio, el área de control debió haber sido cortada el último año. En el área tratada el aclareo no es necesario por lo menos en 3 a 4 años. 